\title{
Food utilisation in fingernail and pill clams
}

\author{
TEREZA KořínKOVÁ \\ Department of Zoology, Charles University, Faculty of Science, Viničná 7, CZ-12844 Praha 2, e-mail:korinko1@natur.cuni.cz
}

KořínKovÁ T., 2011: Food utilisation in fingernail and pill clams. - Malacologica Bohemoslovaca, 10: 1-4. Online serial at $<$ http://mollusca.sav.sk $>18$-Feb-2011.

\begin{abstract}
The contents of digestive systems in six freshwater bivalve species of the family Sphaeriidae were investigated. Microorganisms in the stomachs and intestines of the bivalves were the same as found suspended in the water, which implies none or very limited preingestive selection, at least of the organic particles. Most of the organisms (coccal algae, diatoms, flagellates, euglenophytes, Zygnematophycaea, monadoid algae, bacteria) probably pass through the digestive system unharmed, as they were found alive even in the alimentary bolus in the hindgut. Probably only a small proportion of them is digested, in particular the bacteria and monadoid algae, the abundance of which decreased especially following starvation. In starved animals, food particles were also present in the digestive diverticula, apparently in order to increase food utilisation.
\end{abstract}

Key words: Sphaeriidae, digestive system, filtration, ingestion, water microorganisms

\section{Introduction}

Eulamellibranchiate bivalves are typically filter-feeders. The suspension of potential food particles is pumped in through the inhalant opening or siphon. It also contains some indigestible elements, the proportion of which is regulated during filtration on the ctenidia and labial palps by the rejection of some heavier particles in the form of pseudofaeces. Some authors believed the particles in the suspension to be sorted only by physical forces without any active selection prior to entering the digestive canal (JORGENSEN 1996, WAy 1989). However, the rejection rate of inorganic particles has been found to depend on the concentration of suspended organic matter (HAwKINS et al. 1998, Wong \& Cheung 1999, BAyne et al. 1987), which is an argument in favour of the concurrent hypothesis supposing physiological regulation of food uptake (BAYNE 1998).

The incoming current then proceeds through the mouth to the oesophagus, which connects to the stomach, followed by an intestine. The latter can be divided into the midgut (the part containing typhlosoles and the crystalline style), the coiled intestine, and the hindgut, with the anus positioned near the posterior adductor.

In the stomach, further sorting takes place, facilitated by movements of epithelial cilia. The crystalline style helps mechanical sorting (and perhaps also disintegration) of the particles and produces enzymes (ReID 1968, MorTON 1973). The style itself undergoes cyclic periods of abrasion and reformation (secretion of the crystalline style matter by epithelial cells), at least in intertidal bivalves (MORTON 1973). This implies the digestion is a discontinuos, cyclic process. The general mechanism of digestion as described below has been studied mostly in marine species, but it is with all probability similar in freshwater lamellibranchiates as well. Sorted food particles pass into the digestive diverticula, the blind tubules of which probably are invol- ved in the secretion of enzymes (esterases and endopeptidases, REID 1968), absorption and intracellular digestion (OWEN 1955). Waste products are sent back to the intestine to join rejection currents from the sorting area.

Some inorganic particles that are not rejected as pseudofaeces and pass through the digestive system might facilitate the mechanical breakdown of food particles (NAVARRo et al. 1996). The organic particles found inside bivalve digestive systems have been identified as mostly diatoms, small dinoflagellates and naked flagellates (REID 1968). BougRIER et al. (1997) reported preferential ingestion of flagellates and rejection of diatoms in marine lamellibranchiates Crassostrea gigas and Mytilus edulis. Under laboratory conditions, bivalves have been fed with monoalgal diets (NAVARRo et al. 1996), mixtures of various microscopic algae, and plant detritus (Charles \& Newell 1997).

The primarily freshwater clams of the family Sphaeriidae often dominate among benthic invertebrates of lotic and lentic ecosystems. Detailed anatomical and histological descriptions of their digestive tracts are given by, for instance, Monk (1928) or Holopainen \& Lopez (1989). The mechanism of food intake in Sphariidae differs to some extent from that typical for the most bivalves (MitropolSKiI 1966, Holopainen 1985, Lopez \& Holopainen 1987). Sphaeriids do not maintain a direct contact with the water column. They rather burrow into the substrate and draw the incoming current into their mantle cavity by an active process, probably facilitated by a cilial groove on the foot (Mitropolskir 1966). Therefore, sphaeriid clams should be characterized as interstitial suspension-feeders (HoLOPAINEN \& LOPEZ 1989) or deposit-feeders (WAY 1989) rather than filter-feeders. Filtration of food particles is likely to occur, too, but it might play a minor role. MitropolSKII (1966) has measured the filtration rate in Sphaerium corneum and stated that filter-feeding is in this case not sufficient to cover the energy needs. Also the studies of Hornbach et al. (1984) and Raikow\& Hamilton (2001) 
have proven prevalence of deposit- over filter-feeding in sphaeriids.

Although the mechanism of food intake has been so widely studied, there is a lack of data on the food preferences of sphaeriid clams, but the range of potentional food sources would probably be as broad as in the case of marine species. LOPEZ \& Holopainen (1987) suggest that interstitial bacteria, including saprophytic ones, form the main part of Pisidium diet, whereas larger Pisidium species and Sphaerium and Musculium feed mainly on phytoplankton. Raikow \& Hamilton (2001) hypothesized about preferential utilization of algae by Sphaerium. Foe \& KNIGHT (1986) succeeded in feeding Corbicula fluminea (family Corbiculidae, a group related to Sphaeriidae) for 30 days in laboratory culture with an artificial diet including unicellular green algae of the genus Ankistrodesmus. However, as the authors themselves have pointed out, the clams were losing weight during the experiment, suggesting that the monoalgal diet was not an optimal resource of food. The only information on diet of Sphaeriidae in rearing comes from Mackie \& Flippance (1983), who reported the utilisation of coccal algae and leaf litter as nourishment of Musculium securis grown in laboratory conditions.

\section{Material and methods}

The clams were sampled during summer 2009 from three sites in the Czech Republic: the Vltava River in Prague (shallow littoral zone with sandy bottom, $50^{\circ} 05^{\prime} \mathrm{N}$, $14^{\circ} 25^{\prime}$ E, species: Sphaerium corneum, S. rivicola, Pisidium supinum), the Rokytka stream in Prague (small stream, width ca. $1 \mathrm{~m}$, depth ca $0.5 \mathrm{~m}$, with sandy bottom, $50^{\circ} 04^{\prime} \mathrm{N}, 14^{\circ} 36^{\prime} \mathrm{E}$, species: $S$. corneum, $P$. casertanum) and a small temporary drain in the Poodři Protected Landscape Area (maximum depth $20 \mathrm{~cm}$, muddy bottom, surface overgrown by vegetation, coordinates $49^{\circ} 42^{\prime} \mathrm{N}, 18^{\circ} 05^{\prime} \mathrm{E}$, species: $S$. nucleus, $P$. milium). The specimens were originally collected to dissect out the gonads, gills and larval stages for karyological experiments. The digestive tracts thus remained intact and could be used for wet mounts in a drop of water. The narcotisation (by immersion into water saturated with carbon dioxide) and dissections of the animals were carried out immediately after collection (three specimens of each species from a collection site) or after a certain period of starvation in clear water (three groups of animals killed after 24, 48, 72 hours; each group contained three specimens of each species, the specimens being of different age and size classes). The parts of the digestive tracts (oesophagus, stomach, digestive diverticula, intestine) were treated separately. The exterior of each organ was carefully rinsed in distilled water, then a longitudinal section was led through the wall of the organ, the contents of which were extracted into a drop of water using a preparation needle. The preparations were covered with a cover slip and immediately observed under a light microscope in normal light or under differential phase contrast at $\times 100$ magnification. All organisms in the visual field were counted; the mean from 10 randomly chosen, non-overlapping visual fields was used to estimate the total number of each taxon in the sample. Approximately 0.51 water samples and water-leaches of the sediments from natural habitats were, after centrifugation to a convenient concentration, also inspected for microorganisms. These were primarily classified according to their morphological characteristics and mechanical properties, resulting in some algae being determined to the genus or species level, whereas other organisms could only be identified as "coccal bacteria" or "spirochaetes".

\section{Results}

No oesophagus of any species investigated contained microorganisms. Microorganisms found in the digestive tract and the water sample were principally the same (Fig. 1): coccal bacteria, which dominated in number (estimate $10^{4}-10^{5}$ in adult $S$. corneum), spirochetes, monadoid algae, diatoms (Fragilaria, Navicula, Pinularia, Tabelaria), green algae (Scenedesmus, Coelastrum, Eudorina sp., Pediastrum simplex, P. duplex, Volvox sp.), Zygnematophycae (Closterium, Zygnema, Cosmarium), ciliophores (in particular Oligotrichea), euglenophytes.

The diversity and abundance of organisms in the digestive tract of freshly captured clams was very similar to that of the surrounding water. Some specimens of Pisidium differed in containing smaller number of green algae, ciliophores and diatoms (Fig. 1 c) than Sphaerium did. Apart of that, no striking differences in stomach and intestine content were found between clams representing different species or age classes. Epithelia of the stomach and intestine retained some of their physiological activity even a few hours after the narcotisation and death of the animal: their cilia were still beating in the wet mounts. In spite of this, most of the microorganisms were apparently alive and intact even in the accumulated material in the hindgut: green algae retained their cytoplasm colour and many of the organisms that are normally able to locomote (some bacteria, euglenophytes, ciliophores) were actively moving. In clams following 48 and $72 \mathrm{~h}$ of starvation, the stomach contained less green algae, but these were found intact in the intestine, implying that their tough cell walls allow them to pass through the digestive tract unharmed. The proportion of bacteria in the intestine decreased markedly after starvation, and they, together with some coccal algae were also the only microorganisms found in the digestive diverticula - the organ where part of the digestive process takes place.

\section{Discussion}

This study presents a brief overview on occurrence and abundance of selected groups of microorganisms in the digestive tracts of the sphaeriid freshwater clams (Bivalvia: Sphaeriidae).

The oesophagus was always depleted of any particles which implies very rapid passage of the ingested suspension through this muscular organ. The following parts of the digestive tract contained the same microorganisms as the water and sediments from the locality. Most of them passed unchanged through the digestive system rather than being utilised. Probably it is mainly the inorganic particles that are rejected in the form of pseudofaeces, on account of their size and weight, but a detailed analysis of the pseudo- 
faeces should be made to confirm this supposition.

JORGENSEN (1996) suggested that the particles are captured by the gill apparatus mainly by means of a fluid mechanical process, characterized by a low Reynolds number (i.e. laminary flow). The process would thus be governed by the fluid velocity and by physical properties of the particles rather than by their digestibility or nutritive value. The present observations are in accordance with this expectation.

Most of the microorganisms occurring suspended in the water are probably indigestible thanks to their cell wall or - in the case of diatoms - resistant frustula. The persistence of food particles in the stomach after three days of starvation can be explained 1) by a slow passage of the solid particles through digestive tract even in normal conditions, and 2) by stopping through flow and enhancing utilisation as the concentration of suspended particles in the water decreases. The decrease in abundance of bacteria and some algae in the stomach and their presence in the digestive diverticula after starvation would imply they are probably digested preferentially (or exclusively). Another, though less probable explanation for the distribution pattern of bacteria would be that some of them are symbionts facilitating digestion of some nutrients, and that these symbionts die out when the nutrient income stops.

No apparent interspecific differences have been found with respect to the utilization of particular groups of microorganisms. The small abundance or absence of green algae, ciliophores and diatoms in some specimens of Pisidium might support the suggestion of Holopainen (1985) that smaller Pisidium species feed mainly on bacteria whereas larger Sphaerium species utilize phytoplankton. However, it might also be a mere consequence of the fact that clams with smaller body size are not able to ingest larger particles. In the specimens investigated by myself, the stomach and intestine contents were mostly composed of the same microorganisms as found in the surrounding water. It was not possible to test for differences between the composition of the water suspension and that of the sediment leaches. Therefore, it cannot be estimated what proportion of food particles came from filtration of the water current or from deposit-feeding, respectively.

Some elegant laboratory experiments with monocultural diets containing selected microorganisms (e.g. only monadoid algae, only euglenophytes, diatoms etc.) would provide better knowledge about the possibility of the digestion of the non-preferred components in the absence of the preferred ones. The design of the reported experiment also
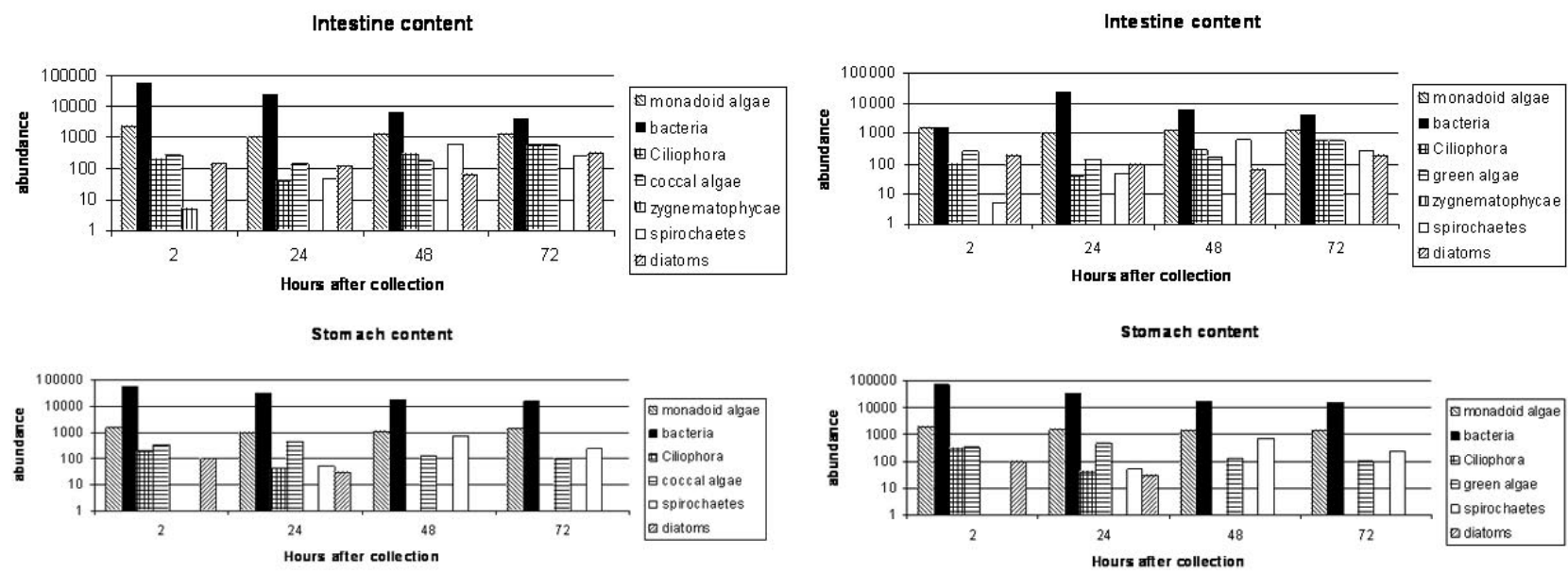

A
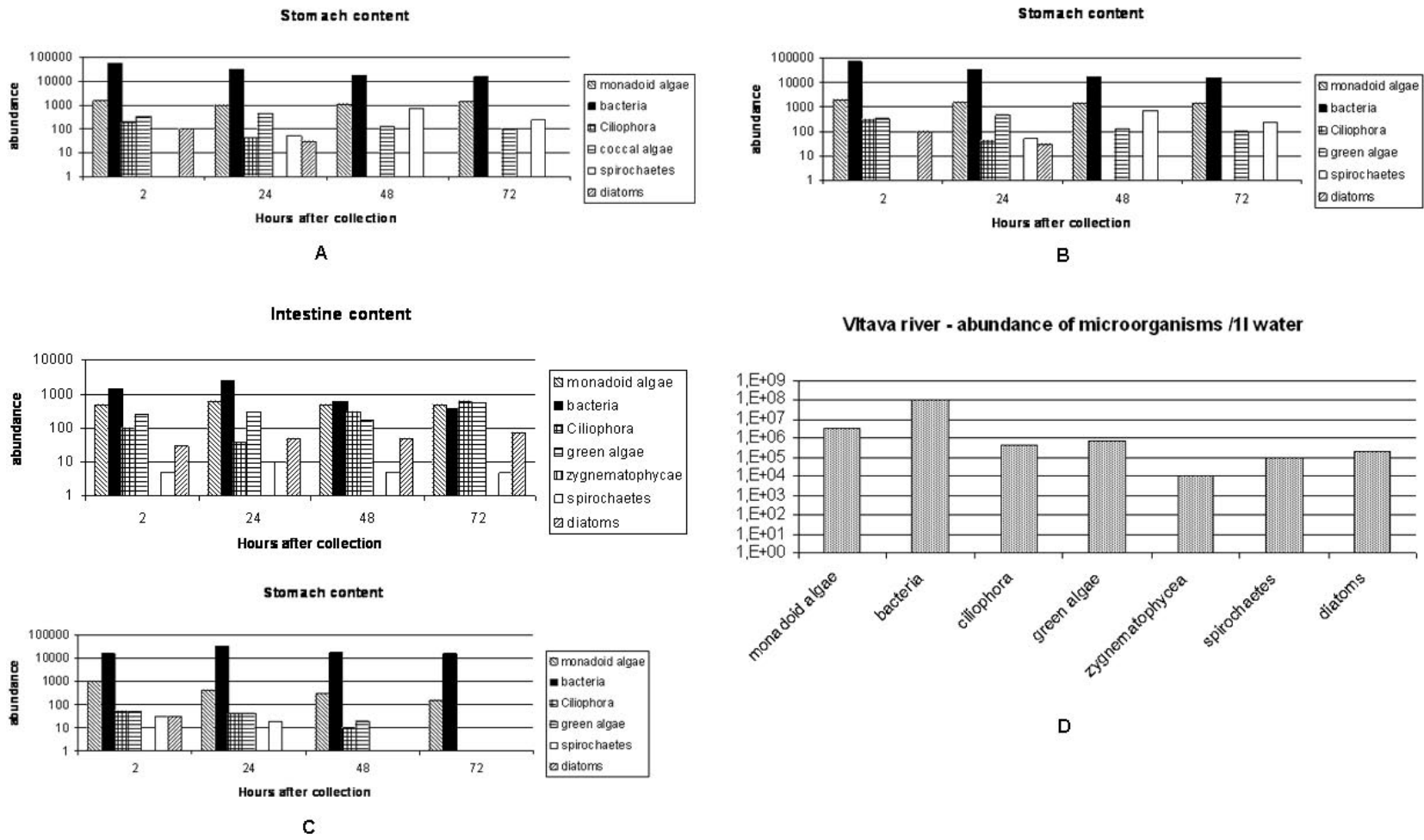

Fig. 1. An example of changes in the stomach and intestine content of sphaeriid clams from the Vltava River during starvation: mean abundances of the most important groups of microorganisms counted from the three specimens dissected in each time period. A) Sphaerium corneum, B) S. rivicola, C) Pisidium supinum, from the Vltava River, D - abundance of microorganisms in 11 of water from the collection site (Vltava River). Note the logarithmic scale of abundance. 
did not allow evaluating ingestion and digestion of organic detritus, the particles of which could be hardly quantified by means of light microscopy and might nevertheless be one of the preferentially digested food components.

\section{Conclusion}

The present study confirmed the absence of any special sorting mechanism which would allow freshwater sphaeriid clams (Bivalvia: Sphaeriidae) to ingest preferentially the utilisable food particles. Microorganisms of suitable size that are found suspended in the water pass into the bivalves' stomach. Some of them are then disintegrated by the action of the crystalline style and digested, but the most continue their passage through the digestive tract without any disruption and often even stay viable. The results suggest small detritus particles (not detectable by the method used) or bacteria as the main source of nutrients for the small freshwater bivalves.

\section{Acknowledgements}

The author is indebted to the colleagues from the Invertebrate Zoology Research Group (Charles University in Prague), namely to J. Smrž for providing the facilities for observation of the preparations, to J. Čepička for valuable discussion concerning freshwater protists and to L. Juřičková for her comments to the manuscript. I also thank to J. Hutchinson (State Museum of Natural History, Görlitz) for a language revision and to a referee for critical comments on the manuscript.

\section{References}

Bayne B.L., Hawkins A.J.S. \&. Navarro E., 1987: Feeding and digestion by the mussel Mytilus edulis L. (Bivalvia: Mollusca) in mixtures of silt and algal cells at low concentrations. - Journal of Experimental Marine Biology and Ecology, 111: 1-22.

BAYNE B.L., 1998. The physiology of suspension feeding by bivalve molluscs: an introduction to the Plymouth "TROPHEE" workshop. - Journal of Experimental Marine Biology and Ecology, 219: 1-19.

Bougrier S., Hawkins A.J.S. \& Héral M., 1997: Preingestive selection of different microalgal mixtures in Crassostrea gigas and Mytilus edulis, analysed by flow cytometry. - Aquaculture, 150: 123-134.

Charles F. \& Newell R.I.E., 1997: Digestive physiology of the ribbed mussel Geukensia demissa (Dillwyn) held at different tidal heights. - Journal of Experimental Marine Biology and Ecology, 209: 201-213.

Foe C. \& Knight A.W., 1986: Growth of Corbicula fluminea (Bivalvia) fed artificial and algal diets. - Hydrobiologia, 133 155-164.
Hawkins A.J.S., Bayne B.L., Bougrier S., Héral M., Iglesias J.I.P., Navarro E., Smith R.F.M. \& Urrutia M.B., 1998: Some general relationships in comparing the feeding physiology of suspension-feeding bivalve molluscs. - Journal of Experimental Marine Biology and Ecology, 219: 87-103.

HolopaINEN I.J., 1985: Feeding biology of Pisidiidae (Bivalvia) with special emphasis on functional morphology of the digestive tract. - Lammi Notes, 12: 5-9.

Holopainen I.J. \& Lopez G.R., 1989: Functional anatomy and histology of the digestive tract of fingernail clams (Sphaeriidae, Bivalvia). - Annales Zoologici Fennici, 26: 61-72.

HornBACH D.J., Wissing T.E. \& BURKY J., 1984: Energy budget for a stream population of the freshwater clam Sphaerium striatinum Lamarck (Bivalvia: Psidiidae). - Canadian Journal of Zoology, 62: 2410-2417.

JoRgENSEN C.B., 1996: Bivalve filter feeding revisited. - Marine Ecology Progress Series, 142: 287-302.

LOPEZ G.R. \& Holopainen I.J., 1987: Interstitial suspension-feeding by Pisidium spp. (Pisidiidae: Bivalvia): a new guild in the lentic benthos? - American Malacological Bulletin, 5 (1): 21-30.

MACKIE G.L. \& FlipPanCE L.A., 1983: Calcium sources for growth of Musculium securis. - Canadian Journal of Zoology, 61: 874-878.

MitropolskiI V.I., 1966: On mechanisms of filtration and nutrition of sphaeriids (Mollusca, Lamellibranchiata). - Trudy Instituta Biologii Vnutrennich Vod Akademii Nauk SSR, 12: 129-133. (in Russian)

Monk C.R., 1928: The anatomy and life-history of a freshwater mollusc of the genus Sphaerium. - Journal of Morphology, 45: 473-503.

Morton B., 1973: A new theory of feeding and digestion in the filter-feeding lamellibranchia. - Malacologia, 14: 63-79.

Navarro E, Iglesias J.I.P., Peréz-Camacho A. \& Labarta U., 1996: The effect of diets of phytoplankton and suspended bottom material on feeding and absorption of raft mussels (Mytilus galloprovincialis Lmk). - Journal of Experimental Marine Biology and Ecology, 198: 175-189.

Owen G., 1955: Observations on the Stomach and Digestive Diverticula of the Lamellibranchia. The Anisomyaria and Eulamellibranchia. - Quarterly Journal of Microscopical Science, 96: 517-537.

RAIKow D.F. \& HAMILTON S.K., 2001: Bivalve diets in a midwestern U. S. stream: a stable isotope enrichment study. - Limnology and Oceanography, 46 (3): 514-522.

ReID R.G.B., 1968: The distribution of digestive tract enzymes in lamellibranchiate bivalves. - Comparative Biochemistry and Physiology, 24: 727-736.

WAY C.M., 1989: Dynamics of filter-feeding in Musculium transversum (Bivalvia: Sphaeriidae). - Journal of National American Benthological Society, 8: 243-249.

Wong W.H. \& Cheung S.G., 1999: Feeding behaviour of the green mussel, Perna viridis (L.): Responses to variation in seston quantity and quality. - Journal of Experimental Marine Biology and Ecology, 236: 191-207. 